Article

\title{
Scanning Saint Amandus: Medical Technologies and Medieval Anatomies
}

\section{Jack Hartnell}

Department of Art History and Archaeology, Columbia University, New York, NY, USA

\begin{abstract}
Anatomy -- the practice of stripping back the body and revealing it, part by part, for discussion and debate -- is a process much explored by the medical humanities, and it presents rich intellectual and practical potential for medieval studies. Tracing anatomical tendencies in the actions of both modern practitioners and inhabitants of the medieval past, this article advocates for anatomy's addition to the rostra of bodily discourses at the disposal of historians of medieval culture. Posited as a critical framework in its own right, notions of anatomy, autopsy, and a literal bodily reading offer us new ways of opening up medieval studies today in much the same way as medieval bodies were once opened on the slab.
\end{abstract}

\section{Essay}

Most sweet Lord, I entreat that it please you that I may be then cut up and opened before you, my Lord and my master, in the same way that certain bodies are dissected before the surgeons in the schools at Montpellier and elsewhere... Henry of Grosmont, duke of Lancaster, Le Livre de seyntz medicines (1354)

There is, in a sense, an anatomical instinct. Charles Singer, A Short History of Anatomy (1957)

In 2007, a thirteenth-century casket reliquary of Saint Amandus underwent conservation in the technical department of the Walters Art Museum, Baltimore. Originally created to house the 
remains of Amandus, a seventh-century bishop of Maastricht, in its medieval context this shrine functioned to make the saint eminently present in the eyes of the faithful, despite his material presence merely as bones, dust, and tattered cloth. It provided miraculous cure upon contact, interceded in prayer from the abbey church's high altar, and was processed about town, spreading the efficacy of the saint's body to the populace at large (Bagnoli et al., 2010, 129). But the corporeal significance of Amandus's casket does not reside in its medieval history alone.

The reliquary's conservation in 2007 was occasioned by questions concerning the authenticity of the gilded copper panels and enamel plaques that constitute the casket's exterior (Walters Art Museum, 2008). But in their art historical investigations, conservators engaged in an extensive process of close study that repeatedly courted technologies of the medicalised body. Gloved hands dissected sections of the reliquary's copper skin from its wooden core with blades and scalpels. Its metal plaques were investigated microscopically, in the manner of skin or blood samples. Parts of the reliquary were examined by a chemist using X-ray fluorescence to determine the material consistency of its copper plating, with some elements diagnosed as genuine articles of the medieval period and others as later nineteenth-century additions (Giaccai, 2008). And, most dramatically, the entire work was transported to the nearby University of Maryland Medical Center where it was scanned on a Direct Radiography Table, a digital X-ray machine normally reserved for Baltimore citizens still alive (see Fig. 1).

\section{[Fig. 1. The thirteenth-century casket reliquary of Saint Amandus undergoing radiography scanning, University of Maryland Medical Center, Baltimore, Maryland, 2008]}

These scans provided conservators with a three-dimensional model of the internal structure of the reliquary, showing that its wooden core was intricately crafted from a single piece of oak. With results analysed by both the Walters conservation team and a group of diagnostic radiologists from the Medical Center, the process marked the shrine as an interdisciplinary mediator between 
medieval history and twenty-first-century medicine in a truly collaborative diagnosis of a patient over 800 years old.

What can the case of Amandus's scanning tell us about the relationship between medievalism and the medical humanities? Most obviously, it suggests the potential of medical technologies for historical endeavour. Objects from the medieval past -- not just those of immediate interest to historians of medieval objects, but also the documents and artifacts that form the primary sources of medieval studies more broadly -- might be opened up by medical devices and interpreted with the help of the medical humanities, a discipline already fluent in parsing the implications of such biomedical data. But more than the mere availability of newfound technologies, I would suggest that the processes of bodily opening and medical looking that such modern practices initiate in fact hint at a much longer history. For what the medical humanities also offers medievalists is access to an anatomical critique, a style of thinking, a way of looking through the body both practically and intellectually that evidenced itself in medical and non-medical practices throughout the medieval cultural landscape. A recent re-definition of the medical humanities as a field of critical enquiry asks: 'Can the medical humanities intervene more explicitly in ontological questions -- in particular, of aetiology, pathogenesis, intervention, and cure?' (Viney, Callard, and Woods, 2015, 3). What follows is a resounding 'Yes' from the Middle Ages. Posited as critical frameworks in their own right, notions of anatomy, autopsy, and bodily close-reading can offer a new way of opening up medieval studies today in much the same way that medieval bodies were once opened on the slab.

\section{Medical Technologies and Medieval Bodies}

Bodily technologies have never been far from the analysis and conservation of medieval objects. The earliest interventions of technical science in investigating artefacts of the past emerged in the 1750s, when the French antiquarian Anne Claude de Caylus engaged a group of chemists in the 
study of bandages from a preserved Egyptian mummy in his collection (Nadolny, 2012, 336).

Medieval paintings were at the heart of this new endeavour, with eighteenth- and nineteenthcentury conservators like Christopher Barber and John Haslam carrying out investigations on works as diverse as the wall paintings of St. Stephen's Chapel in Westminster and the oil panels of Jan Van Eyck (Nadolny, 2005). Such efforts multiplied in the later nineteenth century, with Europe's finest scientists -- the likes of Louis Pasteur and Michael Faraday, no less -- co-opted by the École des Beaux-Arts and the National Gallery, respectively, for increasingly institutionalised explorations in the chemical analysis and treatment of paintings. Soon after, in the 1880 s, chemist A.W. Keim began research into paintings at the Akademie der bildenden Künste in Munich, and scientists quickly found themselves welcome in art schools as far afield as Vienna, St. Petersburg, Stuttgart, and Stockholm (Nadolny, 2012, 337ff). By the early twentieth century, it was only a matter of months between rapidly emerging new technologies of medicine appearing in medical use and being turned towards object investigation. Wilhelm Röntgen, for example, published his pioneering work on X-rays, or 'Shadowgraphs,' in late 1895, and by early 1896 radiographers in Dresden and Frankfurt were undertaking the first X-rays of paintings. ${ }^{1}$ By the 1930 s X-rays were being used as evidence during legal cases and were first used to reveal a group of fake Van Gogh paintings by the infamous Berlin forger Otto Wacker (Marijnissen, 2009, 2ff). The results were examined in court not by medical radiographers, but by a German professor of Italian painting.

The co-opting into medieval studies of such medical technologies continued throughout the twentieth century. To better-known practices like the X-ray we might add a host of scientific breakthroughs both familiar and unfamiliar that continue to be turned on objects of all kinds. Ultrasonics, used since the 1950s in pre-natal examination, functions frequently today in analyses of art materials, for example in evaluating the internal stresses and structures of medieval architecture, or in cleaning microscopic layers of dirt from the surfaces of manuscripts or sculpture. Spectrophotometry, an imaging technology that functions by measuring the wavelength of reflected light, originated in the late 1960s as a medical tool to scan the skin for potentially malignant cancer 
cells but soon after began to be used to detect pigment variations in paint, allowing for colourific analysis and reconstruction of medieval painted surfaces. Ultraviolet light likewise allows physicians and radiologists to examine melanomas on skin, whilst in analyses of artworks it enables historians to penetrate layers of paint and varnish on sculpture or painted surfaces. Medical CT scanning first became commercially viable in the 1970s and, as the Amandus reliquary testifies, both bodies and artworks have been sliced by tomographic rays ever since (Saunders, 2008). The 1980s and 1990s saw the emergence of Magnetic Resonance Imaging (MRI) scans in medical practice to provide a comparably un-invasive view into the human body, able also to pierce further through increasingly solid elements of historical objects (Joyce, 2008). And, more recently, advances in the chemical nano-sciences have had twinned medical and conservation applications: molecular-level investigations using Focused Ion Beams (FIBs) are employed in both radiotherapy treatments and the sampling of artworks, with the FIBs used to extract minute, undamaged samples at an atomic level. Such imported bodily technologies do not stem only from the medical realm: terahertz scanning, a form of non-invasive imaging most commonly employed in airport security, has also recently been used to examine medieval wall paintings (Walker et al., 2013).

In the twentieth and twenty-first centuries, such technologies have provided historians with vital new ways of approaching the material culture of the past. Their rise was intricately tied to medicine: through increasing medical demand, breakthrough technologies became reliable, affordable, and portable, allowing art historians to leave hospital facilities and set up conservation laboratories of their own within museums. Yet, as Amandus's trip to the Maryland Medical Center suggests, some technological and intellectual integration with medical institutions still continues. ${ }^{2}$

The conceptual implications of medical and scientific technologies in the visual and aesthetic history of the nineteenth to twenty-first centuries have been extensively discussed, especially in German scholarship. ${ }^{3}$ But the abilities of such technologies to illuminate objects of the past, and the bond such processes form between artifacts and medicine, are rarely commented upon. If the medical humanities are truly to be embraced as 'a critical collaborator -- a role based on 
notions of entanglement, rather than servility or antagonism' (Viney, Callard, and Woods, 2015, 7), then a closer look at one particular technology of the body might help to bring the almost forensic capacity of medico-artistic practice to the fore in a compelling way.

Since the 1970s scientist Maurizio Seracini, director of the University of California-San Diego’s Center of Interdisciplinary Science for Art, Architecture, and Archaeology, has been searching for a lost Leonardo mural. Conceived and executed at the turn of the sixteenth century on the walls of the grand Salone dei Cinquecento in Florence's Palazzo Vecchio, the painting depicted the Battle of Anghiari, a Florentine victory over Milan in 1440. It was long thought to be lost, overpainted with a mural of similar battle scenes by Giorgio Vasari in the 1560s during the extension of the hall for Cosimo I. But the self-appointed 'Art Detective' Seracini had a hunch there was more to this disappearance than met the eye. He was no stranger to forensics: in the 1980s he had used various scanners and imaging technologies to aid Florentine police in the infamous 'Monster of Florence' murders, and sure enough, in the case of the lost Leonardo, Seracini came across a clue. Some sixty feet up, impossible to read from the ground, a flag in the melee of Vasari's battle scene displays a cryptic phrase: 'CERCA TROVA,' seek and you shall find. This Seracini did. Between 2004 and 2011 his team set about analyzing the mural with various instruments appropriate to his media image as a 'high-tech art sleuth' (Pieraccini et al., 2004). Using military radar and lasers to look beneath the walls, Seracini discovered there was a small gap behind the Vasari fresco where, he suggested, the later artist had attempted to preserve the much-admired original mural.

Controversial invasive action was taken in November of 2013. Focusing on areas of the Vasari mural where natural decay had necessitated conservation and re-painting, unoriginal plaster was removed by scalpel in six places, allowing for the insertion of a medical endoscope. Feeding a live stream back to assembled researchers, the camera slowly made its way into the palazzo's interior to take minute samples from inside the wall, a painterly biopsy undergone in the hope of finding Leonardo's missing pigments. For a few brief moments the plaster of Vasari's mural took on human form as Seracini and his team, dressed in white lab coats, slowly fed the technology 
through the wall's orifices into the hidden interior of the Palazzo's gut, later bandaged over like a wounded patient to avoid extensive cracking. In Seracini's own words: 'What I do is analyze the anatomy of a work of art' (Tucker, 2006). In this case, however, the anatomy was left incomplete. Despite finding a small cavity behind the Vasari, Seracini's dissections were called off by local officials before more comprehensive explorations could be made.

Endoscopy, a widely familiar technique for imaging the body's internal organs, has been used with increasing success in art examination, effectively granting the conservator a manipulable, roaming eye able to penetrate spaces the traditional art historical gaze cannot reach. Regardless of Seracini's hotly debated theories, his use of this technology bears out José van Dijck's characterization of the deep and penetrating endoscopic stare as a form of 'epistemological, psychological, and imaginative seduction' (van Dijck, 2005, 80). This is not just an anatomical seduction, a revelatory wonder at the interior of things; in Seracini's case, it is also a narrative seduction. Unsurprisingly, the case of the Leonardo mural captured the imagination of the popular press, spawning numerous mythologizing newspaper articles and television documentaries. The heady cocktail of the Western world's most famous artist and a futuristic art historical detective has even seen Seracini assumed into a popular fictional fabric: he is the only non-fictional individual to appear in Dan Brown's thriller The Da Vinci Code (2003). This detail might seem trivial, but intriguingly such parallels are not new in modern discourse. In an essay written some thirty years earlier -- 'Morelli, Freud, and Sherlock Holmes: Clues and Scientific Method' (1979) -- Carlo Ginzburg attempted to bring historical method into line with just this type of investigative fiction. Eloquently building links between the longstanding conjectural mechanisms of psychoanalysis, the more literary clue-finding of detective fiction, and the influential critic Giovanni Morelli's connoisseurial approach to art historical detail, Ginzburg concludes on the eligibility of each method in the realms of art and science, as well as their fundamental similarities (Ginzburg, 1979). There are many, not least that Morelli, too, is referenced in fiction, noted by Arthur Conan Doyle in the Sherlock Holmes story The Adventure of the Cardboard Box (1892). But Ginzburg's most 
poignant suggestion is that historians working in this vein are not reliant on the clues and deductive reasoning of crime novellas alone; they exhibit a strong concern for a more forensic, medical type of looking too. The Foucauldian notion of the piercing, medicalised gaze -- his highly-theorised 'regard' -- and the power dynamics that inevitably follow from it are certainly reflected in illustrations from the pages of Morelli’s Italian Painters (Foucault, 1963; Morelli, 1892). Greeting the reader with a hotchpotch collection of body parts -- ears, hands, eyes, nostrils, and fingernails, endlessly itemised to their tiniest details -- the mass groupings of dispersed forms severed loose from their accompanying bodies form a historical comparative anatomy. ${ }^{4}$ Designed so as to allow their morphologies to be traced back to individual artists, these fragmented bodies unite the intentions of the historian and the forensic actions of the surgeon, gathering partial faces and limbdetails, presenting them carved up and grouped on the page according to the intentions of an intellectualised dissection.

Historians of twentieth-century medicine have suggested that the origin of imaging technologies like X-rays or CT scans is indicative of a certain Sisyphean quest for a transparent human body, one that the physician might visually dissect with consummate ease in search of cure. The importation of such methods into medieval studies suggests a similar historical urge to see through the bodies of the past in quest of a more accurate, almost anatomical diagnosis. ${ }^{5}$

\section{Medieval Intellectual Anatomies}

Modern technologies imported from medicine can thus offer interesting new methods for medieval studies, ways of unpicking and re-piecing medieval objects and bodies through an interdisciplinary model of medical humanities research. But medical methods like these have another even more potent power to bring out conceptual resonances in practices that are far more long-standing. For

some time, historians of medicine have been excavating a rich medieval history of engagement with the body as object in anatomical and pseudo-anatomical terms. By bringing out this history here in 
brief, I want to suggest that all medievalists -- not just those concerned directly with medicine -might benefit from both its specifics and its methods, opening up a new strand of medieval culture with which we might enrich our practice.

Throughout the thirteenth and fourteenth centuries, an interest in anatomy was growing in the medieval university. The movement of academics between expanding sites of intellectual medicine had ensured the importation of medical texts from prominent early centres like Salerno or from the Islamic world, catalysing the re-emergence not just of formal medical tuition in Western Europe but also the tentative roots of academic post-mortem dissection. ${ }^{6}$ Medicine at the University of Bologna makes for a representative example, not least because its pioneering methods of sourcing, opening, interpolating, and disposing of bodies were exported to most medical establishments in Europe's burgeoning university culture. Here, the first recorded academic dissections appear to have taken place under the supervision of the physician Mondino da Liuzzi in 1315, and it was largely through the success of Mondino's treatise, the Anatomia corporis humani, published a year later in 1316, that Bologna's methods spread so widely. The statutes at Bologna provide us with a number of clues as to how such anatomical teaching was intended to be carried out if and when it occurred. A specific programme for the dissection event is not listed, but they define the size and bureaucratic processes of the anatomy faculty, as well as the provision of bodies to be dissected. ${ }^{7}$

Corpses sent under the knife were required to be those of foreigners born a distance from the city, and they were also likely to be recently executed criminals; this practicality allowed for a bureaucratically neat solution to the problem of the supply of bodies from within a city's own administrative system, and began a strong bond between anatomy and criminality that was to remain well into early modern practice (Sawday, 1995). With corpses supplied sporadically by the city, it seems likely that these early anatomies took place in the private quarters of teachers who carried out the instruction, although this was clarified in changes to the statutes in 1442, whereafter the podestà (chief magistrate) supplied the university with a fixed number of two cadavers per 
year. ${ }^{8}$ With an audience almost exclusively of scholars and students, the primary intention of these early practices was insistently didactic. Moreover, they were in no way research-led, but rather were intellectualised occasions on which description was more valuable than novel observation, the body effectively functioning as an extended illustration whose ritual opening and anatomising down to its smallest elements was used to reaffirm the veracity of longstanding, pre-existing medical theories and texts (Carlino, 1994). As well as Mondino's Anatomia, the first fen of Avicenna's Canone and Galen's De usu partitum corporis humani were commonly intoned whilst the body was opened, their passages of classical learning forming the basis for discussion of the body and its parts. From these Bolognese roots, dissection became increasingly popular in the scholastic medieval mindset. Corpses underwent recorded anatomies in Montpellier from around 1340, Florence and Perugia from 1348, Padua from 1363, Florence from 1372, Venice from 1386, Lerida from 1391, and Vienna from 1404 (Siraisi, 1990). ${ }^{9}$

Contemporaneous images of the dissection event are rare, although the few that do exist shed a little more light on its specific details. Some are relatively schematic scenes: the figures accompanying the 1345 Anathomia Designata per Figures of Guido Vigevano, for example, show an anatomist opening several generically rendered sections of a grey, cadaverous body (MS 334, Musée Condé, Chantilly). More detailed, however, are later images from the early era of print, where we find depictions of what was by the fifteenth century the university dissection scene's consistent format. A print from the Fasciculus Medicinae, a medical book first printed in Venice in 1493 and associated with (but not written by) the German physician John of Ketham, may be read in conjunction with the university statutes to reveal such anatomical processes in action. ${ }^{10}$ The cadaver is set out on a makeshift wooden table, surrounded by an audience of academic students and fellows debating in the quodlibetal style around the corpse. Sitting at a tall cathedra, looking not unlike a priest at the pulpit, is the figure of the lector, a high-ranking academic who was responsible for reading aloud the chosen part of the Latin text about to be verified against the corpse. Below, two figures from the group of dissectors further highlight the medieval process of 
stripping the corpse. Leaning over the cadaver with a long knife in hand is the sector, poised to make the first incision as specified by Mondino from sternum to pubis. Beside him, directly above the head of the cadaver, stands the figure of the ostensor or demonstrator. Likely the most senior figure on the dissection floor, he indicates the next stage of the dissection, engaging in a translation of the lector's Latin for the comprehension and guidance of those gathered around him. It was also the role of the ostensor to encourage the disputatio of the quodlibet around him.

In the three key figures of the dissection chamber -- lector, sector, and ostensor -- we see personified three principal elements of the practice prized from the very beginning of anatomical dissection's re-emergence in the Western European medical school: the reading of anatomical texts, the affirmation of their values and details through the purely illustrative dissection of the body, and their further discussion or explanation within medieval canons of scholastic reasoning. It is perhaps no coincidence that these roles -- reading, dissecting, and explaining -- also all contain something of the investigative process undergone by Saint Amandus in 2007: the text's historical claims, once expounded, demand substantiating and pique a certain curiosity; the knife's fricative workings peel back the object's barriers; and the translation connects text with body, and medicine with history, in order to produce firmer conclusions and questions for debate.

\section{Anatomy Across the Medieval Landscape}

The textually-motivated anatomies of the medieval university were not, however, the only medical engagement with the opened body in the period. As the medical humanities have consistently affirmed, medicine does not exist in isolation to broader culture but rather is engaged in an ongoing dialogue with other aspects of society. Following this lead, we might begin to think about the presence of the anatomised medieval body outside of the academy, in medieval culture more broadly. 
In the earlier Middle Ages, the quotidian medicine of physicians and surgeons -- alongside a whole host of less learned medical professionals -- had long been engaging with the opened body in various ways, courting the humoral curative potential of letting blood, lancing warts and boils, examining bodily egestions and the colour of urine, and amputating gangrenous limbs. But by the early thirteenth century the situation had changed. Secular and religious restrictions on surgical practices, as well as new social pressures emerging from university scholarship, had in much of Europe initiated a separation between the hands-on practice of medicine and its intellectual counterparts. ${ }^{11}$ Practical surgery was not welcome in most universities, and the annual use of cadavers to verify text was the nearest learned academic physicians got to literally probing the body's secrets. Yet manual surgery was far from moribund and was strongly maintained within craft structures of local guild systems: workshops, masters, and apprentices contributed to a flourishing and distinctly manual profession. Such surgeons appear to have been socially ambitious in two directions. On the one hand, over the course of the thirteenth and in particular the fourteenth centuries, surgical writers like Roger Frugardi, Guglielmo da Saliceto, Henri de Mondeville, and Guy de Chauliac engaged in a campaign of latinate treatise writing, an attempt to give their profession at least some intellectual parity with the textual traditions of university physicians. On the other hand, surgeons were at the same time keen to make clear their distinction from the field of theoretical medicine, emphasising their position as highly capable and specifically practical craftsmen, unafraid to get their skilled hands dirty. Surgeons, barber-surgeons, and empirics were highly active in this liminal position between intellectualised and non-academic worlds, and quantitative studies reveal that they made up a substantial proportion of the medical professionals available to urban populations (Jacquart, 1998, 84ff). Deeply knitted into the fabric of everyday life in any medieval city, surgeons provided care in a number of public locations, from town squares to church narthexes and naves. Combined with other concentrated activities relating to the open body in the context of the medieval street -- public executions, civic punishment, occultism, or butchery, to name but a few -- we can begin to entangle the valuable work of historians of surgery with other 
fields of medieval studies to form a view of everyday medieval life in which anatomical sights and ideas were overtly apparent.

Judicial practices of the late Middle Ages, for example, further popularised the practice of opening bodies to reveal their hidden contents in medieval legal contexts. The first firm textual reference to a post-mortem dissection of a human body occurs in the chronicle of the Franciscan monk Salimbene of Parma, written in 1288, and records a case two years earlier in which a plague victim's body was opened at the thorax to compare markings on the tip of their heart with those discovered on the heart of a hen struck down with a similar disease (Park, 1994). Surgical investigations like these were more common than is usually thought, with Salimbene's record unlikely to be the first; earlier in the thirteenth century, Pope Innocent III ordered medical professionals to engage in an autopsy of a criminal who was beaten to death whilst attempting to steal objects from a church (O'Neill, 1976). By the turn of the fourteenth century, we find even firmer evidence for such autopsies in the service of the judiciary in several Italian states, where doctors were regularly recruited to testify in trials based on both external and internal assessments of bodies. One of the first of these official autopsies was the anatomy of Azzolino degli Onesti in 1302, his body opened by the Bolognese physician and academic Bartolomeo Varignana in order to determine the extent of toxic substances in his stomach, the evidence of which would serve to indict or absolve a suspected poisoner. Five years later in 1307, a woman named Ghisetta was opened to confirm a ruling that she had died from internal bleeding; around the same time a Paduan apothecary was revealed through autopsy to have died from mercury poisoning (French, 1999; Park, 1994). It is clear that, by this point, medieval populations were becoming accustomed to the notion that a human body might be opened and screened to reveal certain fundamental truths.

As well as being closely linked to judicial verification, the procedures of anatomy were also intertwined with medieval funerary practices. Although these rituals varied from place to place and across different social classes, opening the body in order to embalm it before burial was commonplace, especially in the thirteenth century. In their treatment of the corpse, these burial 
practices were in some places indistinguishable from more formal post-mortems, with contemporary writers even referring to funerary preparations as 'anatomies' or 'anatomical' in nature, another etymological blurring (Park, 2006, 6). Such parallels are likewise made clear in contemporary surgical treatises, with medieval surgeons like Mondeville and Guy de Chauliac outlining embalming procedures in their writings, encouraging entry to the body either through a central cut down the thorax, or in the shape of an inverted shield beneath the stomach. This reciprocity continued in further centuries, with private anatomies carried out by independent physicians associated with local medical schools, requested by those who could afford them in order to provide a cause of death or warn of potentially hereditary or congenital conditions. Other more extreme practices, for example the complicated tradition of dispersing body-parts of the deceased French and English royalty, suggest even grander political motivations for the postmortem division of society's prized and powerful bodies (Warntjes, 2012). Indeed, it is not just in the royal or aristocratic realm that we find exhibited a curiosity for the body's internal workings. Not only did the much-documented medieval culture of relic veneration ensure anatomised body parts were present in nearly all religious settings, but recent investigations have also identified a number of more invasive, saintly autopsies undertaken in the same period. In 1308, only six years after Onesti's well-publicised toxicity investigations, the body of Umbrian holy-woman Chiara of Montefalco underwent a thoroughly unorthodox, gradual, three-day anatomy performed by her fellow nuns (Park, 2002). Carried out with the intention of preserving the holiness of their abbess's body, upon opening Chiara's corpse her dissectors cut open her heart to find an image of the crucified Christ, the crown of thorns, the whip and column, rod and sponge, and miniature nails of the passion, all rendered in the heart's very flesh and sinews. She was not the only holy woman to undergo such treatment: Saint Margaret of Citta di Castello underwent an autopsy on the altar of her local church where her dissectors reportedly discovered three stones in her aorta inscribed with a nativity scene (Warr, 2007). In these religious events, intricately linked to the Italianate culture of autopsy at the time, the opened body could reveal things previously hidden. 
In all of these areas -- academic, quotidian, legal, and religious -- what remains clear is that anatomy was prevalent as both an intellectual and practical endeavour. On the one hand, such practitioners saw the body afresh, yet on the other they saw within the corpse only what they wanted to find. Through delving beneath the skin of cadavers, holy and lay alike, the corpse's contents were revealed and read as part of a process of gleaned knowledge, investigations that look forward to the deconstruction of St. Amandus's casket by conservators. The frequency and diversity of these sources suggest that both practical and conceptual processes of anatomy should be as prominent in the minds of medieval historians as they appear to have been across the contemporary medieval world.

\section{Looking Through the Body in Medieval Culture}

Even this cursory socio-cultural survey of medieval anatomy presents an insistent picture of a revelatory, dissective interest in the practice across Europe in the period. But in closing I want to bring us back full circle to the way we treat objects and documents of the Middle Ages today, and back also to the new histories we might weave if we can utilise the critical medical humanities not simply as a coincidence of anatomical method but as a tangible link between the medical and the medieval.

If we can see that a prominent form of anatomical thinking existed in the Middle Ages, we might surely also begin to read its influences within a variety of its cultural products: a medieval medical humanities. Historians of literature, for example, have been intertwining medieval writing and notions of the body for some time, spawning a vast secondary bibliography. Yet this attention does not always comment on the relation of medieval writings on society and politics, religion and philosophy, or courtly love and romance to the specifically medical ideas that often underpin them. A medieval medical humanities might question, for example, how political writings that speak of the symbiotic 'body politic' relate to various medical metaphors of rupture, dismemberment, and 
healing; how Eucharistic and other religious doctrines present as their foundation various scientific and medical theories of human digestion, death, and decay; and how courtly romances interact with a larger genre of literature heavily influenced by medical conceptions of gender and sexual difference. Likewise, as the study by Marie-Christine Pouchelle (1983) has shown, there is fruitful work to be done in the consideration of surgical treatises themselves as literary products, charting their various techniques, metaphors, phraseologies, and bodily structures across a wide range of written products in the late medieval period.

Similarly, in the visual arts, medicine and anatomy might have a vital role to play. As with many spheres of medieval history, a paucity of information often spells the end of art historical endeavour, a scarcity of sources making the task of understanding the physical, aesthetic, and intellectual contexts of artworks particularly difficult, if not impossible. But a medieval medical humanities offers anatomy and its bodily counterparts as a potential way of extending our abilities to discuss and understand artworks in such uncertain terrain. The positioning of goldsmiths and painters in medieval guilds alongside surgeons and apothecaries, for example, hints at the potential consonance of their crafts. The conducting of surgeries by medieval medical professionals inside public spaces like churches adds yet another complex layer to the social function of architecture. And the presence of artworks in all of the anatomical contexts outlined above, both inside and outside the academy, suggest new avenues of research for objects as diverse as funerary monuments, saintly image cycles, or the grander accoutrements of royal and judicial power. Moving beyond the notion that anatomy is only of relevance to historians of medicine, medievalists at large might build on such material to expand their conceptual correlatives into a multitude of new areas. What a newfound awareness of this medical knowledge might instill in the medievalist is the ability to look through the medieval body. This looking is at once literal and metaphorical: it is not just the practical, rummaging, blood-stained image of an anatomist searching for a diagnosis, or a conservator with the transparent gaze of an X-ray or CT scanner; it is instead to look through a 
bodily frame, conceptualising the anatomist's revelatory medical work as a means to understand the past with an invigorated perspective.

Historiographically, the medical humanities sits within an incessantly affirmed and yet rarely defined interdisciplinarity, and in this medicine is often presented as a sister field which holds a familiar ambiguity. On the one hand its approaches are clearly of use to us as medievalists, even vital: we fill our terminologies with bodily labels; we co-opt its sciences of the eye and the mind and their implications in world-views and philosophical perspectives; and we absorb the interrogative techniques of therapists and analysts, asking Socratic questions of our inherently unanswering sources. Yet, on the other hand, medievalism wears its entry into medicine with a hesitancy common to such ventures, for parallel disciplines are arenas in which a non-specialist is not always welcome. As useful as their various tenets may seem, medicine and its histories come complete with different values and parameters, where the humanities specialist can seem at best unsure and at worst ignorant. But we must shed this uneasiness at the idea of a medical-medieval interchange, for it has a two-fold capacity to bring out of medieval culture both something new and something much older, its modern technological function always sitting alongside its wider-ranging import in the original mindset of the Middle Ages. In particular, anatomy should be placed into the rostra of bodily discourses at the disposal of historians of medieval culture. After all, given the case of Amandus, it is not as unlikely as we might think for the medievalists to find themselves manning machines and enacting techniques that, both practically and intellectually, peel back the delicate skins of medieval bodies to peer beneath them.

\section{Notes}

1. The German physicist may himself have inadvertently encouraged ties between X-rays and art: his earliest experiments photographed both human hands and lead white paint. 
2. It is reductive to say that historians and conservators rely entirely upon medicine and the movement is not always one-way: resources of conservation departments are sometimes made available to police, with art historical equipment used to forensically sample human tissue.

3. See Bredekamp et al. (2008); Bruhn and Dünkel (2008); Kormeier (2010); Pasveer (2005); Geimer (2002). These works respond to and influence English scholarship, for example, Elkins (2007) or Cartwright (1995).

4. See Wind (1963); Wollheim (1973); Carrier (2003).

5. Titles of several recent publications in art conservation bear out this urge: Andrea Kirsch and Rustin Levenson speak of Seeing through Paintings (2000), David Bomford searches for A Closer Look (2009), and Erma Hermens advocates Looking Through Paintings (2007).

6. Gallo (2008); Savage-Smith (1995).

7. See Malagola (1888); Carlino (1994). Carlino (1994) references similar statutes at Genoa, Perugia, Pisa, Florence, and Padua.

8. See Park (2006); Ferrari (1987).

9. For Italy, see Carlino (1994) and Siraisi (1981); for Paris, see Jacquart (1998) and Pouchelle (1983); for Montpellier, see Dumas (2014); on Germany, see Nutton (1998).

10. See Pesenti (2001); Bylebyl (1990). Select images from the book can be browsed via the National Library of Medicine website: https://ceb.nlm.nih.gov/proj/ttp/flash/ketham/ketham.html. 11. See McVaugh (2006); Carlino (1994); Brown (1981).

\section{About the Author}

Jack Hartnell is Lecturer in Art History at the University of East Anglia, Norwich, where his research and teaching focuses on the visual culture of late medieval and early Renaissance science and medicine. In 2015-17 he was Mellon Postdoctoral Fellow and Lecturer at Columbia University, New York, before which he held fellowships at The Courtauld Institute of Art, the Victoria and 
Albert Museum, and the Max-Planck-Institut für Wissenschaftsgeschichte in Berlin (E-mail: j.hartnell@uea.ac.uk).

\section{References}

Bagnoli M., et al. 2010. Treasures of Heaven: Saints, Relics, and Devotion in Medieval Europe. Baltimore, MD: Walters Art Museum.

Bomford, D. 2009. A Closer Look: Conservation of Paintings. London: National Gallery.

Bredekamp, H., et al. 2008. Das Technische Bild: Kompendium zu einer Stilgeschichte wissenschaftlicher Bilder. Berlin, Germany: Akademie Verlag.

Brown, E.A.R. 1981. Death and the Human Body in the Later Middle Ages: The Legislation of Boniface VIII on the Division of the Corpse. Viator 12: 221-70.

Bruhn, M. and V. Dünkel, 2008. The Image as Cultural Technology. In Visual Literacy, ed. J. Elkins, 166-78. New York: Routledge.

Bylebyl, J. 1990. Interpreting the Fasiculo Anatomy Scene. Journal of the History of Medicine and Allied Sciences 45: 285-316.

Carlino, A. 1994. La fabbrica del corpo. Turin, Italy: Einaudi.

Carrier, D. 2003. In Praise of Connoisseurship. Journal of Aesthetics and Art Criticism 61(2): 15969.

Cartwright, L. 1995. Screening the Body: Tracing Medicine's Visual Culture. Minneapolis, MN: University of Minnesota Press.

Dumas, G. 2014. Santé et société à Montpellier à la fin du Moyen Âge. Leiden, The Netherlands: Brill.

Elkins, J., ed. 2007. Visual Practices Across The University. Munich, Germany: Wilhelm Fink. Ferrari, G. 1987. Public Anatomy Lessons and the Carnival: The Anatomy Theatre of Bologna. Past \& Present 117(1): 50-106. 
Foucault, M. 1963. Naissance de la Clinique. Une Archéologie du Regard Médical. Paris: Presses Universitaires de France.

French, R. 1999. Dissection and Vivisection in the European Renaissance. Aldershot, UK: Ashgate.

Gallo, I. 2008. Salerno e la sua scuola medica. Napoli, Italy: Guida.

Geimer, P. 2002. Ordnungen der Schitbarkeit. Fotografie in Wisssenscharft, kunst und Technologie. Frankfurt, Germany: Suhrkamp.

Giaccai, J. 2008. X-ray fluorescence of a medieval Mosan reliquary of Saint Amandus. (paper presented at the 57th Annual Denver X-ray Conference, Denver, Colorado, 4-8 August 2008).

Ginzburg, C. 1979. Morelli, Freud, and Sherlock Holmes: Clues and Scientific Method. History Workshop 9: 5-36.

Hermens, E. 2007. Looking Through Paintings. London: Archetype.

Jacquart, D. 1998. La Médecine Médiévale dans le Cadre Parisien. Paris: Fayard.

Joyce, K.A. 2008. Magnetic Appeal: MRI and the Myth of Transparency. Ithaca, NY: Cornell University Press.

Kirsch, A. and R. S. Levenson. 2000. Seeing through Paintings. New Haven, CT: Yale University Press.

Kormeier, U. 2010. Innere Werte: Kunst im Röntgenlicht. Trajekte 11: 4-9.

Malagola, C., ed. 1888. Statuti delle Universita e dei Collegi dello Studio Bolognese. Bologna, Italy: Zanichelli.

Marijnissen, R.H. 2009. The Masters' and the Forgers' Secrets. X-Ray Authentication of Paintings from Early Netherlandish Till Modern. Brussels, Belgium: Mercatorfonds.

McVaugh, M. 2000. Surgical Education in the Middle Ages. Dynamis 20: 283-304.

McVaugh. M. 2006. The Rational Surgery of the Middle Ages. Florence, Italy: SISMEL.

Morelli, G. 1892. Italian Painters: Critical Studies of Their Work. London: John Murray.

Nadolny, J. 2005. A Problem of Methodology: Merrifield, Eastlake, and the Use of Oil-based 
Media by Medieval English Painters. In ICOM-CC $14^{\text {th }}$ Triennial Meeting Preprints, ed. I. Verger, 1028-33. London: James and James.

Nadolny, J. 2012. A History of Early Scientific Examination and Analysis of Painting Materials c.1780 to the Mid-twentieth Century. In Conservation of Easel Paintings, ed. J.H.

Stoner and R. Rushfield, 336-41. New York: Routledge.

Nutton, V. 1998. Medicine at the German Universities, 1348-1500: A Preliminary Sketch. In Medicine from the Black Death to the French Disease, ed. R.K. French et al., 85-109. Aldershot, UK: Ashgate.

O’Neill, Y.V. 1976. Innocent III and the Evolution of Anatomy. Medical History 20(4): 429-33.

Park, K. 1994. The Criminal and the Saintly Body: Autopsy and Dissection in Renaissance Italy. Renaissance Quarterly 47(1): 1-33.

Park, K. 2002. Relics of a Fertile Heart: The ‘Autopsy’ of Clare of Montefalco. In The Material Culture of Sex, Procreation, and Marriage in Premodern Europe, eds. A.L. McClanan and K.R. Encarnacion, 115-33. New York: Palgrave Macmillan.

Park, K. 2006. The Secrets of Women. Cambridge, MA: MIT Press.

Pasveer, B. 2005. Representing or Mediating? A History and Philosophy of X-Ray images in Medicine. In Visual Cultures of Science, ed. L. Pauwels, 41-62. Hanover, NH: Dartmouth College Press.

Pesenti, T. 2001. Fasiculo de medicina in volgare, Venezia, Giovanni e Gregorio De Gregori, 1494. Vols 1 and 2. Treviso, Italy: Antilia.

Pieraccini, M., et al. 2004. A High-Frequency GPR Application to the Cultural Heritage Survey: The Search for The Battle of Anghiari by Leonardo da Vinci. In Proceedings of the Tenth International Conference on Grounds Penetrating Radar, ed. E. Slob et al., 391-4. Delft, The Netherlands: Delft University of Technology.

Pouchelle, M-C. 1983. Corps et Chirurgie à l'apogée du Moyen Age. Paris: Flammarion.

Röntgen, W.C. 1896. 'On a New Kind of Rays' read before the Würzburg Physical and Medical 
Society, 1895 (trans. Arthur Stanton). Nature 53: 274.

Saunders, B. 2008. CT Suite: The Work of Diagnosis in the Age of Noninvasive Cutting. Durham, NC: Duke University Press.

Savage-Smith, E. 1995. Attitudes Toward Dissection in Medieval Islam. Journal of the History of Medicine and Allied Sciences 50: 68-111.

Sawday, J. 1995. The Body Emblazoned. New York: Routledge.

Siraisi, N.G. 1981. Tadeo Alderotti and His Pupils. Princeton, NJ: Princeton University Press.

Siraisi, N.G. 1990. Medieval and Early Renaissance Medicine. Chicago, IL: University of Chicago Press.

Tucker, N. 2006. Maurizio Serracini: The Man Behind the Real Da Vinci Mystery. The Florentine 46: $1-4$.

van Dijck, J. 2005. The Transparent Body. Seattle, WA: University of Washington Press.

Viney, W., F. Callard, and A. Woods. 2015. Critical Medical Humanities: Embracing Entanglement, Taking Risks. Medical Humanities 45(1): 2-7.

Walker, G.C., et al. 2013. Terahertz Analysis of Stratified Wall Plaster at Buildings of Cultural Importance Across Europe. Proceedings of SPIE [online publication], 30 May, doi:10.1117/12.2020596.

Walters Art Museum. 2008. Unravelling the Mysteries of The Saint Amandus Shrine. October, http://www.youtube.com/watch?v=FYwLD0b0AyA.

Warntjes, I. 2012. Programmatic Double Burial (Body and Heart) of the European High Nobility, c.1200-1400. In Death at Court, ed. K-H. Spieß and I. Warntjes, 197-259. Wiesbaden, Germany: Harrassowitz.

Warr, C. 2007. Re-Reading the Relationship Between Devotional Images, Visions, and the Body: Clare of Montefalco and Margaret of Città di Castello. Viator 38: 217-249.

Wind, E. 1963. Art and Anarchy. London: Faber.

Wollheim, R. 1973. Giovanni Morelli and the Origins of Scientific Connoisseurship. In On Art and 
the Mind: Essays and Lectures, ed. R. Wollheim, 177-201. London: Lane. 